\title{
Patterns of Infection with the Nematodes Syphadia obvelata and Aspiculuris tetraptera in Conventionally Maintained Laboratory Mice
}

\author{
Telma Bazzano, Tamy Ingrid Restel, Roberto Magalhães Pinto*/++, \\ Delir Corrêa Gomes* ${ }^{+} /^{++}$
}

\author{
Biotério do Centro de Ciências Biológicas e da Saúde, UFMS, Campo Grande, MS, Brasil *Laboratório de Helmintos Parasitos \\ de Vertebrados, Departamento de Helmintologia, Instituto Oswaldo Cruz-Fiocruz, Av. Brasil 4365, 21045-900 \\ Rio de Janeiro, RJ, Brasil
}

\begin{abstract}
Data on the frequency, distribution and mean intensity of the helminth fauna recovered from outbred and inbred mice conventionally maintained in Brazilian animal houses, are reported. The oxyurid nematodes Syphacia obvelata and Aspiculuris tetraptera presented overall frequencies of $91.5 \%$ and $8.5 \%$, respectively. The frequency of $\mathrm{S}$. obvelata in animals of three groups out of the four investigated ranged from $9 \%$ to $74 \%$ and A. tetraptera from $17 \%$ to $83 \%$, since animals of one of the groups were negative for helminths. Infections due to a single species were observed in $62 \%$ of the animals, compared to $16 \%$ related to associations. The frequency of single infections in each group varied from $58.6 \%$ to $100 \%$ whereas associations varied from $24.1 \%$ to $41.4 \%$. The analysis of specific mean intensities showed that $\mathrm{S}$. obvelata was represented by 13.35 to 66.58 specimens/host and A. tetraptera by 5.85 to 16.75 specimens/host.
\end{abstract}

Key words: nematodes - Syphacia obvelata - Aspiculuris tetraptera - laboratory mice - Mato Grosso do Sul - Brazil

Laboratory animals are suitable and necessary for the proper development of several biological assays. The utilization of these standard models is recommended aiming at the attainment of reliable and reproductible results. In despite of this approach, laboratory animals are seldom investigated for autochthonous ecto and endoparasites prior to their utilization in experiments. In conventional, semi-open facilities, rodent colonies are frequently infected with helminths. These parasites, if undetected, can interfere in the development of protocols and alter the interpretation of final results (Pinto et al. 1994, 2001, Gonzalez 1996, Luca et al. 1996, Gonçalves et al. 1998). The analysis of different biological parameters related to the presence of nematodes in mice conventionally kept in animal houses in which sanitary conditions and barriers have not been properly controlled, is presented.

\section{MATERIALS AND METHODS}

From August 1999 to January 2000, 116 adult male mice [(Mus musculus (Linnaeus, 1758)] 42 days old, mean weight $28 \mathrm{~g}$, conventionally maintained in four institutional facilities in Campo Grande, State of Mato Grosso do Sul, Brazil, were randomly chosen to be investigated for helminths. For ethical reasons, suppliers were not named and are identified as groups A, B, C, D, according

${ }^{+}$Corresponding author. Fax: $+55-21-2598.4361$. E-mail: dcgomes@ioc.fiocruz.br

${ }^{++}$Research fellows CNPq, proc. 300374/80-1 and 303124/89-1

Received 30 November 2001

Accepted 25 February 2002 to their source. Each group contained 29 animals: groups A, B, D of outbred Swiss Webster (SW) mice and group C of inbred BALB/c mice. Climatization in the four animal facilities (A, B, C and D), at the moment that the animals were received, was achieved by means of air conditioning devices and natural ventilation. For animals of group A, values of temperature and relative humidity were obtained with a thermohygrometer and daily measurements registered in the morning and afternoon. The values were included in charts so to obtain daily, monthly, semestral and annual profiles. Semestral values from August 1999 to January 2000 ranged from $25.14^{\circ} \mathrm{C}$ (morning) to $26.46^{\circ} \mathrm{C}$ (afternoon) whereas the relative humidity values were of $59.7 \%$ (morning) and $57.3 \%$ (afternoon). Sanitary control of animals of group A consisted in semestral ecto and endo parasitological examination. Temperatures of $\mathrm{B}$ and $\mathrm{D}$ facilities were obtained daily with a thermometer and mean temperatures were of $24 \pm 2^{\circ} \mathrm{C}$. General husbandry, maintainance procedures and sanitary conditions are in Table I.

Animals were sacrificed in an ether chamber according to ethical procedures (Apa 1989) and necropsied in accordance to Pinto et al. (1994). Cecum and colon were opened longitudinally in individual Petri dishes with an $0.85 \% \mathrm{NaCl}$ solution. Nematodes were recovered alive and identified under a stereoscope microscope and fixed in a hot $10 \%$ formaldehyde solution. Classification of the nematodes follows Pinto et al. (1994). Deposited material: Helminthological Collection of the Oswaldo Cruz Institute 34667, 34668 (wet material).

For the quantification of specific worm burdens, six ranges of distribution were considered (Pinto et al. 1994) as follows: I: 1-20, II: 21-40, III: 41-60, IV: 61-80, V: 81- 100, VI: + 100. Ecological terms (frequency, distribuition and mean intensity) are in accordance to Bush et al. (1997). 
TABLE I

Husbandry and maintenance of mice

\begin{tabular}{|c|c|c|c|c|}
\hline \multirow{2}{*}{$\begin{array}{l}\text { Maintenance } \\
\text { Groups }\end{array}$} & \multicolumn{2}{|c|}{ Animal } & \multicolumn{2}{|c|}{ Facility } \\
\hline & A & $\mathrm{B}$ & $\mathrm{C}$ & $\mathrm{D}$ \\
\hline \multicolumn{5}{|l|}{ Ambiental control } \\
\hline Temperature & Yes & Yes & No & Yes \\
\hline Relative humidity & Yes & No & No & No \\
\hline Periodical sanitary control & Yes & No & No & No \\
\hline \multicolumn{5}{|l|}{ Hygiene and biosecurity } \\
\hline Material sterilization & No & No & Yes (bottles) & No \\
\hline Disinfection & Yes & Yes & Yes (cages) & Yes (cages) \\
\hline Cages cleaning & 2x/week & 2x/week & 2x/week & 2x/week \\
\hline General cleaning & Weekly & $2 \mathrm{x} / \mathrm{month}$ & $2 \mathrm{x} / \mathrm{month}$ & $2 \mathrm{x} / \mathrm{month}$ \\
\hline Room cleaning & $3 \mathrm{x} /$ week & Weekly & weekly & Weekly \\
\hline Appropriate clothing & Yes & No & No & No \\
\hline Restrictions (jewelery, cosmetics) & Yes & No & No & No \\
\hline Bath & 2x/day & No & No & No \\
\hline Overall changing & 2x/day & Daily & Daily & Daily \\
\hline Shoes protector changing & 2x/day & Daily & Not utilized & Not utilized \\
\hline \multicolumn{5}{|l|}{ Staff } \\
\hline Professionals in animal care & Yes & No & No & No \\
\hline Trainees & Yes & Yes & No & No \\
\hline
\end{tabular}

The age, mean weight of animals and mean intensities of infections were analyzed by means of Graph Pad Instant statistical program and the ANOVA test.

The development of the present protocol has been authorized by the Committee of Ethics for the Use of Animals (CEU-Fiocruz), no. P0072-01.

\section{RESULTS}

Mean values of weight and age of animals were evaluated in the different groups (Table II). The nematodes Syphacia obvelata (Rudolphi, 1802) Seurat, 1916 (Figs 1a,b) and Aspiculuris tetraptera (Nitzsch, 1821) Schulz, 1924 (Figs 2a,b) were recovered from the investigated mice. Total number of worms was of 2,885. S. obvelata was represented by 2,613 specimens with a frequency of $91.5 \%$, compared to 242 A. tetraptera worms with a frequency of $8.5 \%$ (Fig. 3). The highest frequency of S. obvelata occurred in the SW mice of group B with 1,931 worms (74\%) followed by those of group D, with 455 worms (17\%). In the group $\mathrm{C}$ of BALB/c mice, 227 worms (9\%) were recovered; the highest frequency of $A$. tetraptera was observed in mice of group B, with 201 worms $(83 \%)$, whereas in mice of group D, with 41 worms, the frequency was of $17 \%$ (Fig. 4). Animals of group A were not parasitized.

According to the pattern of worm burden distribution, S. obvelata appeared in a larger number of mice in range I. Parasitism in mice of group B, was distributed in all ranges; in mice of group $\mathrm{C}$ worm burdens were represented in ranges I-III (Fig. 5b) and those of group D, in ranges I-III and V (Fig. 5c). Similar patterns were observed for infections with $A$. tetraptera: the largest number of parazitized mice harbored worm burdens included in range I; animals of group B presented burdens in ranges I, IV and V (Fig. $5 a)$. Parasitism in mice of group $D$ was represented only in range I (Fig. 5c).
Statistical analysis of mean intensities of parasitism with $A$. tetraptera did not show significant differences between the groups B and D $(16.75 \pm 28.59$ and $5.85 \pm$ 5.46) and between the groups $C$ and D (13.35 \pm 14.17 and $17.5 \pm 19.90)$ with mice infected with $S$. obvelata; nevertheless, significant differences related to the mean intensities of parasitism by $S$. obvelata were observed in the comparison of mice of groups B and C $(66.58 \pm 82.75$ and $13.35 \pm 14.17)$ and those of groups B and D $(66.58 \pm 82.75$ and 17.5 \pm 19.90$)$ (Table III).

\section{DISCUSSION}

The improvement of laboratory animals either considering genetic approaches in the utilization of homogeneous strains or on the basis of sanitary conditions in an attempt to maintain these animals free from pathogens is a priority, since undetected autochthonous parasitic infections in laboratory animals, even in the absence of clinical signs, may act as variables, during experimental assays (Eaton 1972, Saiz-Moreno et al. 1983, Jacoby \& Fox 1984, Huerkamp 1993, Pinto et al. 1994, 2001, Sato et al. 1995, Rehbinder et al. 1996, Rosas 1997, Gonçalves et al. 1998, Ortiz et al. 2000). In conventional animal facilities, rodent colonies are frequently infected with helminths or become infected in the laboratories where they are mantained in the course of experiments.

The age of the mice to be utilized is a parameter to be considered in the evaluation of pre-existing worm burdens in these experimental hosts. According to Flynn (1973) and Jacoby and Fox (1984), infections with $S$. obvelata generally occur in young mice, since adults seem to be more resistant; thus, 4-5 weeks mice should be investigated considering that prevalences of worm burdens are higher at this time. Panter (1969) and Taffs (1976) reinforce the acquired resistance to infection between the 4th 
TABLE II

Values (mean \pm standard deviation) of weight and age of mice

\begin{tabular}{lcccc}
\hline Groups & A & B & C & D \\
\hline Weight & $27.62 \pm 4.87 \mathrm{a}$ & $33.34 \pm 3.86 \mathrm{~b}$ & $23.76 \pm 3.60 \mathrm{c}$ & $29.72 \pm 4.07 \mathrm{a}$ \\
Age (days) & $41.34 \pm 11.68 \mathrm{a}$ & $48.00 \pm 4.81 \mathrm{~b}$ & $40.72 \pm 8.51 \mathrm{a}$ & $45.45 \pm 4.17 \mathrm{~b}$ \\
\hline
\end{tabular}

ANOVA test $(\mathrm{p}<0.05), \mathrm{n}=29$; values in the same line, with the same letter are not significantly different.
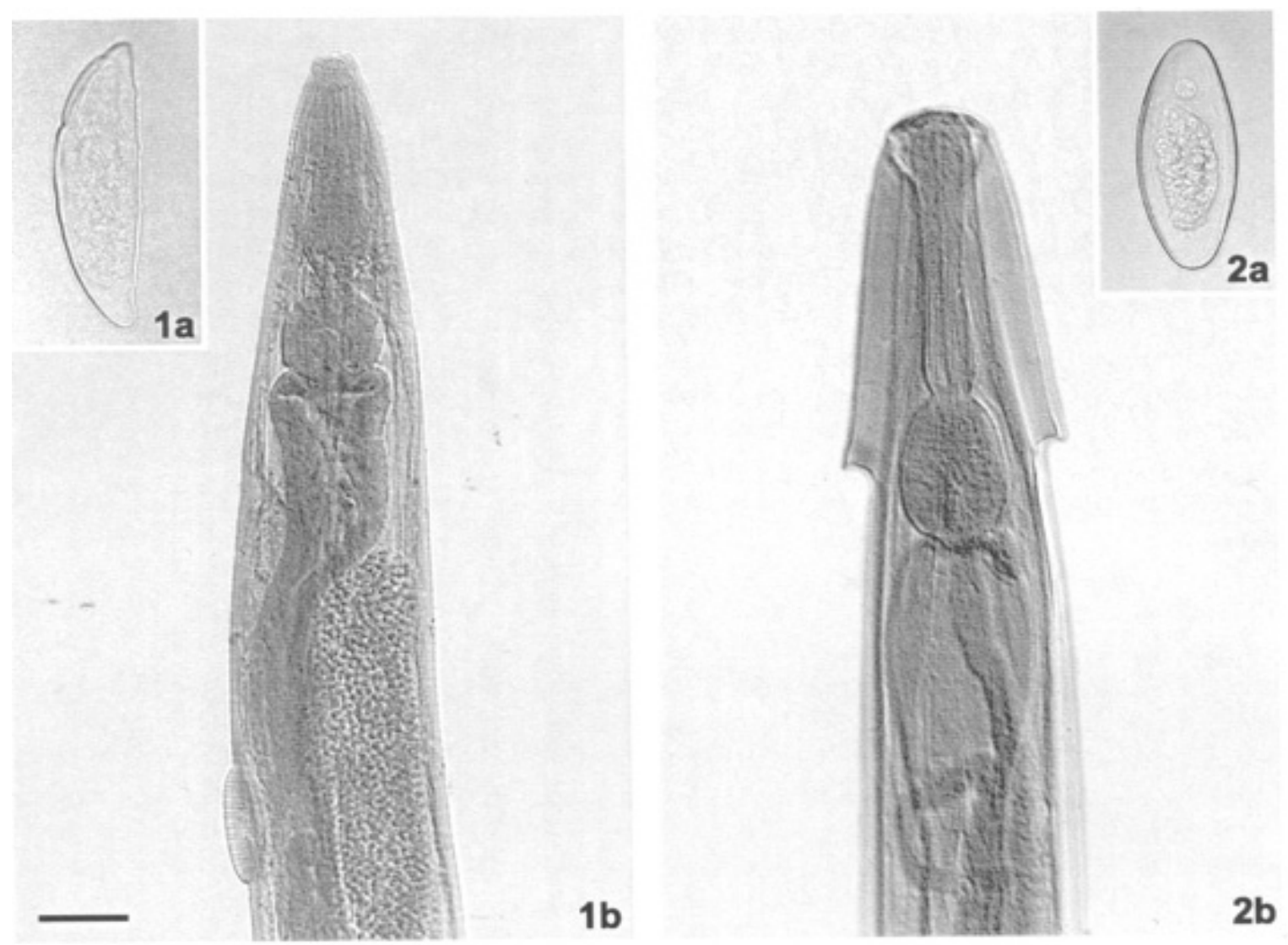

Fig. 1: Syphacia obvelata. a: egg $(\mathrm{bar}=0.03 \mathrm{~mm})$; $\mathrm{b}$ : anterior extremity $($ bar $=0.02 \mathrm{~mm})$. Fig. 2 : Aspiculuris tetraptera. a: egg $($ bar $=0.02$ $\mathrm{mm})$; b: anterior extremity (bar $=0.05 \mathrm{~mm}$ ). Bar common to Figs 1 and 2 . Figs $1 \mathrm{~b}$ and $2 \mathrm{~b}$ were obtained in a Differential Interference Contrast (DIC) system.

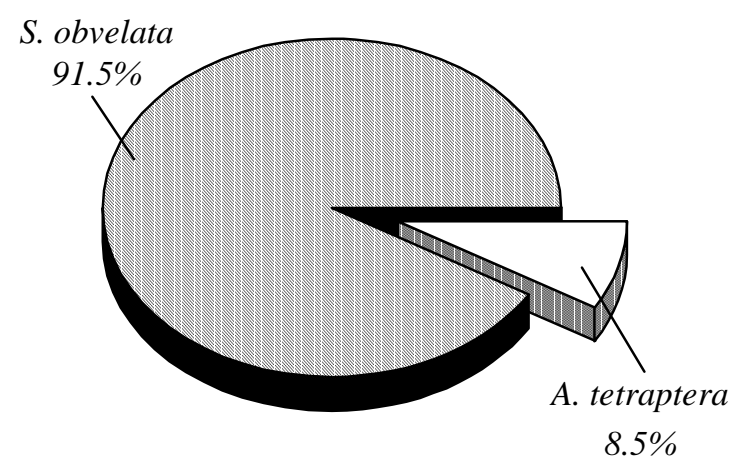

Fig. 3: frequency of Syphacia obvelata and Aspiculuris tetraptera.

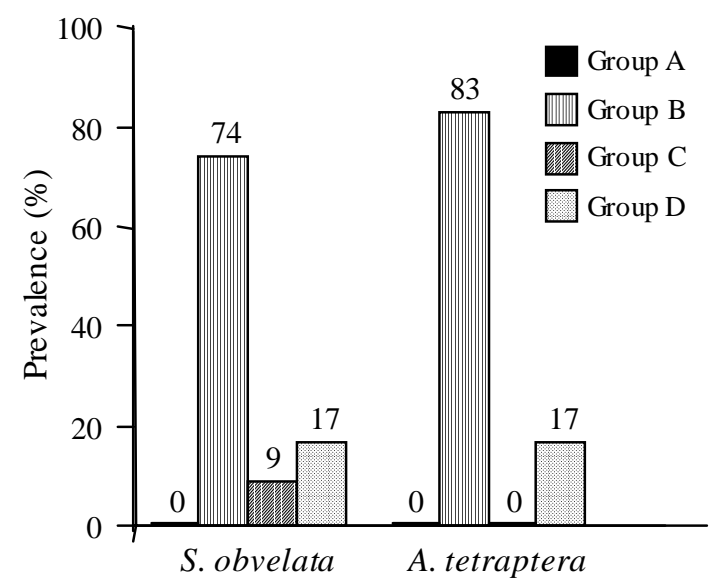

Fig. 4: frequencies of Syphacia obvelata and Aspiculuris tetraptera in mice of different groups. 
and 9th weeks after birth, whereas infections with $A$. tetraptera affect older mice. Taffs (1976) reported to the age related resistance in mice, associated to an increase of mucus production and to the natural aging physiological process; nevertheless, no specific immune response was detected. Mean values of ages, related to worm burdens recovered, are in accordance with data previously reported (Flynn 1973, Jacoby \& Fox 1984).
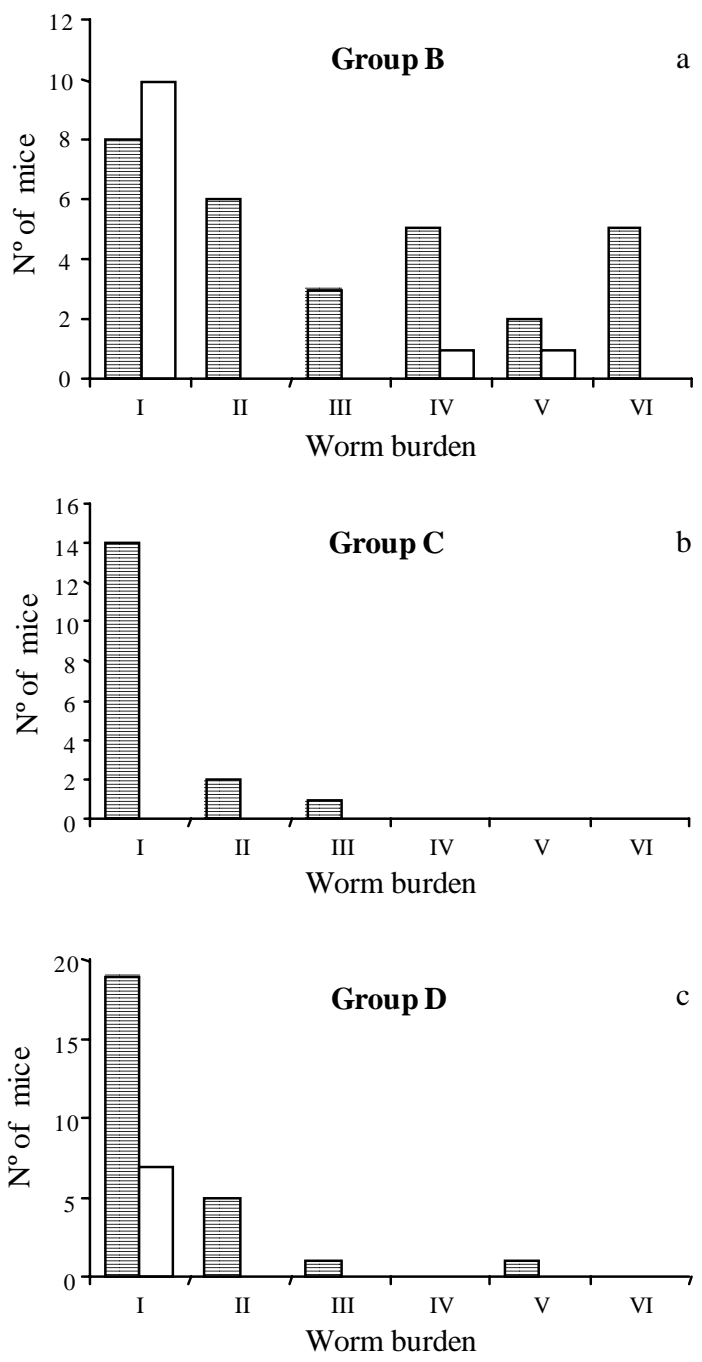

S. obvelata $\square$ A. tetraptera

Fig. 5a-c: distribution of worm burdens, according to the different ranges. I: 1-20 worms; II: 21-40 worms; III: 41-60 worms; IV: 6180 worms; V: 81-100 worms; VI: + 100 worms.
The high frequency of S. obvelata in comparison with A. tetraptera worm burdens presently observed is not in accordance with Rosas (1977) that reports higher frequencies of the latter species; nevertheless, this high frequency of $S$. obvelata in rodent colonies is justified considering the nematode life-cycle, that is shorter in this species, thus inducing the infection in a larger number of mice in short periods (Flynn 1973, Jacoby \& Fox 1984, Scott \& Gibbs 1986, Coghlan et al. 1993, Moulia et al. 1993, Klement et al. 1996, Zenner 1998).

Gonçalves et al. (1998) observed associations of $S$. obvelata and A. tetraptera in outbred and inbred mice; this parameter is to be analyzed with basis on the population dynamics of pinworms in mice, as previously reported (Scott \& Gibbs 1986). Hayunga (1991) and Gonçalves et al. (1998) agree in the statement that associations of different helminth species in a same host specimen induce the establishment of competition for nutrients and overgrowth of the parasites; however, according to Scott and Gibbs (1986) this competition is not related to the habitat since the site of infection of $S$. obvelata is the cecum, while A. tetraptera is recovered mainly from the colon; thus, this factor is not to be considered as the principal in these associations.

In the comparison of the present results with those reported by Gonçalves et al. (1998) referring to worm burdens, inbred mice investigated here, harbored smaller parasite loads and are in accordance with Higgins-Opitz et al. (1990) and Moulia et al. (1995) that refer to lower prevalences of $S$. obvelata in inbred mice strains.

The distribution of worm burdens evaluated in the present study agrees with previous data (Anderson \& Gordon 1982, Pinto et al. 1994). According to Anderson and Gordon (1982), the aggregation of helminths in the host populations are common to occur under laboratory and field conditions. These aggregates are due to the heterogeneous susceptibility of mice to infections, related either to behavior, genetics background, immunological status or to the concentration of infective eggs in the environment increasing the possibility of accidental infections (Scott \& Gibbs 1986).

The absence of parasites in mice from the animal facility $\mathrm{A}$ is, undoubtely, due to the more adequate adopted procedures and qualified working staff that act as barriers against helminth infections, when compared to animal houses B, C and D (Table I). Despite the fact that cages in the animal facility A are openly cleaned, disinfected and dried under the sun, this aspect seems to improve hygiene conditions, since according to Taffs (1976) oxyurid eggs although highly resistent to the cold and disinfection, are extremely susceptible to sunlight and heat.

TABLE III

Mean intensities and standard deviation of the parasitism by Syphacia obvelata and Aspiculuris tetraptera in necropsied mice

\begin{tabular}{lcccc}
\hline & \multicolumn{4}{c}{ Groups } \\
\cline { 2 - 5 } & A & B & C & D \\
\hline S. obvelata & - & $66.58 \pm 82.75 \mathrm{a}$ & $13.35 \pm 14.17 \mathrm{~b}$ & $17.5 \pm 19.30 \mathrm{~b}$ \\
A. tetraptera & - & $16.75 \pm 28.59 \mathrm{a}$ & - & $5.85 \pm 5.46 \mathrm{a}$ \\
\hline
\end{tabular}

ANOVA test $(\mathrm{p}<0.05)$; values in the same line, with the same letter are not significantly different. 


\section{ACKNOWLEDGMENTS}

To the instituitions which supplied the mice and to Heloisa Maria Nogueira Diniz, Laboratório de Imagens, Instituto Oswaldo Cruz, for technical assistance regarding figures.

\section{REFERENCES}

Anderson RM, Gordon DM 1982. Processes influencing the distribution of parasite numbers within host populations with special emphasis on parasite-induced host mortalities. Parasitology 85: 373-398.

Apa 1989. Código de Ética Experimental com Animais, Sozed, Rio de Janeiro, 8 pp.

Behnke JM 1975. Aspiculuris tetraptera in wild Mus musculus. The prevalence of infection in male and female mice. $J$ Helminthol 49: 85-90.

Bush AO, Lafferty KD, Lotz JM, Shostak AW 1997. Parasitology meets ecology on its own terms: Margolis et al. revisited. J Parasitol 83: 575-583.

Coghlan LG, Lee D, Rick PB, Weiss D 1993. Practical and effective eradication of pinworms (Syphacia muris) in rats by use of fenbendazole. Lab Anim Sci 43: 481-487.

Eaton GJ 1972. Intestinal helminths in inbred strains of mice. Lab Anim Sci 22: 850-853.

Flynn RJ 1973. Parasites of Laboratory Animals, The Iowa State University Press, Ames, 882 pp.

Gonçalves L, Pinto RM, Vicente JJ, Noronha D, Gomes DC 1998. Helminth parasites of conventionally maintained laboratory mice - II. Inbred strains with an adaptation of the anal swab technique. Mem Inst Oswaldo Cruz 93: 121-126.

Gonzalez RH 1996. Producción de roedores dentro de un sistema de barreras. Anim Experim 2: 26-27.

Hayunga EG 1991. Morphological adaptations of intestinal helminths. Parasitology 77: 865-873.

Higgins-Opitz SB, Dettman CD, Dingle CE, Anderson CB, Becker PJ 1990. Intestinal parasites of conventionally maintained Balb/C mice and Mastomys coucha and effects of a concomitant schistosome infection. Lab Anim Sci 24: 246252.

Huerkamp MJ 1993. Ivermectin eradication of pinworms from rats kept in ventilated cages. Lab Anim Sci 43: 86-89.

Jacoby RO, Fox JG 1984. Biology and diseases of mice. In JG Fox, BJ Cohen, FM Loew (eds), Laboratory Animal Medicine, Academic Press Inc., London, p. 31-89.

Klement P, Augustine JM, Delaney KH, Klement G, Weitz JI 1996. An oral ivermectin regimen that eradicates pinworms (Syphacia spp.) in laboratory rats and mice. Lab Anim Sci 46: $286-290$.
Luca RR, Alexandre SR, Marques T 1996. Manual para Técnicos em Bioterismo, Winner Graph, São Paulo, 259 pp.

Moulia C, Le Brun N, Dallas J, Orth A, Renaud F 1993. Experimental evidence of genetic determinism in high susceptibility to intestinal pinworm infection in mice: a hybrid zone model. Parasitolgy 106: 387-393.

Moulia C, Le Brun N, Loubès C, Marin R, Renaud F 1995. Hybrid vigour against parasites in interspecific crosses between two mice species. Heredity 74: 48-52.

Ortiz M, Cabeza GP, González S, Mata EMM 2000. Evaluación de la eficacia y efecto residual de dos desinfectantes usados en puertas, paredes y pisos de cuartos para roedores. Anim Experim 5: 2-3.

Panter HC 1969. Studies on host-parasite relationships: Syphacia obvelata in the mouse. J Parasitol 55: 74-78.

Pinto RM, Vicente JJ, Noronha D, Gonçalves L, Gomes DC 1994. Helminth parasites of conventionally maintained laboratory mice. Mem Inst Oswaldo Cruz 89: 33-40.

Pinto RM, Gonçalves L, Gomes DC, Noronha D 2001. Helminth fauna of the golden hamster Mesocricetus auratus in Brazil. Lab Anim Sci 40: 21-26.

Pinto RM, Gonçalves L, Noronha D, Gomes DC 2001. Worm burdens in outbred and inbred laboratory rats with morphometric data on Syphacia muris (Yamaguti, 1935) Yamaguti, 1941 (Nematoda, Oxyuroidea). Mem Inst Oswaldo Cruz 96: 133-136.

Rehbinder C, Baneux P, Forbes D, Van Herck H, Niclas W, Rugaya ZY, Winkler G 1996. FELASA- Recommendations for the health monitoring of mouse, rat, hamster, gerbil, guinea pig and rabbit experimental units. Lab Anim Sci 30: 193-208.

Rosas GA 1997. Diagnóstico: parasitosis intestinal por Aspiculuris tetraptera. Anim Experim 2: 9-11.

Saiz-Moreno L, Garcia JLY, Compaire FG 1983. Animales de Laboratorio (Producción, Manejo y Controle Sanitario), Min Agricult Pesca y Alimentatión, Inst Nac de Investigaciones Agrarias, Madrid, 593 pp.

Sato Y, Ooi HK, Nonaka N, Oku Y, Kamiya M 1995. Antibody production in Syphacia obvelata infected mice. J Parasitol 8: 559-562.

Scott ME, Gibbs HC 1986. Long-term population dynamics of pinworms (Syphacia obvelata and Aspiculuris tetraptera) in mice. J Parasitol 72: 652-662.

Taffs LF 1976. Pinworm infections in laboratory rodents: a review. Lab Anim Sci 10: 1-13.

Zenner L 1998. Effective eradication of pinworms (Syphacia muris, Syphacia obvelata and Aspiculuris tetraptera) from a rodent breeding colony by oral antihelmintic therapy. $L a b$ Anim Sci 32: 337-342. 
852 Nematode Infections in Mice - Telma Bazzano et al. 